\title{
The Thin Red Line and the World War II Hollywood Tradition
}

\author{
By Eleftheria Thanouli
}

Spring 2005 Issue of KINEMA

\section{THE THIN RED LINE AND THE HOLLYWOOD WORLD WAR II TRADITION}

The Thin Red Line is a three-hour epic about the World War II, directed by Terrence Malick, who made his comeback to the film industry after 20 years with a subject that had been neglected for almost as long. ${ }^{(1)}$ The film is based on James Jones' novel, published in 1962, which was first adapted for the big screen by Andrew Marton in 1964 rather unsuccessfully. For many years, the book seemed to defy cinematic adaptation due to its deliberately choppy, episodic storyline, its lack of a single heroic protagonist and the multiplicity of perspectives. ${ }^{(2)}$ However, Malick tried to overcome these obstacles by creating a film which broke "most of the commercial rules about narrative and drama"(3), as a critic observes. My interest in The Thin Red Line is therefore twofold: firstly, I will try to explore the ambivalent nature of its narrative which oscillates between the Hollywood tradition and art-cinema narration and secondly, I will focus on the representations of war, in an attempt to compare them to the World War II films of the past.

World War II stands out as an intriguing period in the history of Hollywood cinema. After the bombardment of Pearl Harbor and the American involvement in the war in 1941, the Hollywood industry was eager to express its wholesale commitment to the imperatives of war. As Tomas Schatz observes, "never before or since have the interests of the nation and the movie industry been so closely aligned, and never has Hollywood's status as a national cinema been so vital".(4) Hollywood's prompt mobilization, combined with the prominent role of cinema as the dominant mass medium at the time, turned the Second World War into the most thoroughly documented and dramatized event in history ${ }^{(5)}$ Since television and the 24-hour transmission of images were not yet available, it was the motion pictures that brought the war to the wide public through the vast production of newsreels, documentaries and dramatic features. However, despite the abundance of images and representations, all the fiction and non-fiction treatments of the war shared a common message: that the American people fought for a just cause and the war effort had to be sustained at all cost until the final victory.

The representations of armed forces in wartime movies encompass a wide range of films which feature soldiers, sailors and airmen both in combat and non-combat situations. Especially at the outset of the war, the "war themes" were integrated into the already established film genres, such as the musical and the comedy, where the uniformed men functioned merely as props in crowd scenes, in the streets, in night clubs and train stations. ${ }^{(6)}$ However, according to Schatz, "the term war film took on steadily narrower connotations as Hollywood refined specific war-related formulas." (7) These formulas comprised espionage films, occupation films, home-front dramas depicting military training or the daily experience of the wartime Americans, and above all, combat films, which constituted the core of the genre.

The combat movies provided the most direct and all-encompassing treatment of the war by dramatizing the actual battles and inaugurating a new sense of realism and historical immediacy in the Hollywood films. They depicted battlefield situations on sea, land or air, and described the violence, the hardships and the courage of the soldiers in the front. The largest number of combat films produced during the war take place in the Pacific theatre of operations ${ }^{(8)}$ and some of the most legendary examples include Wake Island (1942), Bataan (1943), Guadalcanal Diary (1943) and 30 Seconds Over Tokyo (1944), to name just a few. Hollywood's response to the Japanese attack on Pearl Harbour was not only swift but also relentless. In the combat films, the portrayal of the Japanese as duplicitous and barbaric 'subhumans' had no precedent. As Dick notes, "in contrast to the 'good German' and the occasional good Nazi, good Japanese were almost unheard of." ${ }^{\prime(9)}$

However, in the postwar era the World War II film genre underwent some significant transformations. Although the combat film remained the dominant formula for another two decades, the films looking back at the Second World War adopted a more moderate stance towards the enemy and tried to provide a less biased account of the war. As Manvell observes, "as the years pass, the antagonisms between the former enemies become relaxed into a form of mutual respect for prowess and dedication in war...."(10) Some of 
the most frequently debated films that exemplify this revisionist turn are Attack! (1956), which portrays a conflict within the American army, Tora Tora Tora (1970), which tries to shed light on the circumstances that led the Japanese to attack Pearl Harbor, and Patton (1970) which provides a very controversial portrait of a modern hero. ${ }^{(11)}$ Patton was actually the last commercially successful and critically appraised epic of the Second World War ${ }^{(12)}$ because the war in Vietnam and the establishment of television as the popular mass medium brought about significant changes in the motion picture industry. After remaining in the spotlight for almost four decades, the subject of the WWII was superseded by the more controversial conflict of Vietnam and the contemporary needs of the film market. As Doherty notices,

By the early 1990's conventional Hollywood wisdom considered the 1941-45 background 'box-office poison' because multiplex mall crawlers and the crucial 18-to-24-year-old demographic find Frank Capra's Great Struggle as remote and irrelevant as the Peloponnesian Wars. ${ }^{(13)}$

Some years later, however, in 1998 Hollywood did return to the all-time classic theme of WW II and the Thin Red Line is a very critically appraised example. Nevertheless, the course of time and other events caused considerable transformations to the war genre and my analysis of the film will try to identify them.

\section{Elements of narration in the Thin Red Line}

The Thin Red Line is set in the Guadalcanal Island in the Pacific Ocean in 1942 and depicts the attempt of the American army to seize control over the Guadalcanal Island in the Pacific Ocean and their battles against the Japanese occupiers. The structure of the film is rather episodic and the syuzhet can be analyzed in the following segments:

- The film opens with an idyllic sequence in an unspoiled island in the Pacific. Private Witt (James Caviezel) is absent without leave (AWOL) and he is enjoying his time away from the ugliness of the front. In a voice-over we hear his thoughts about nature, life and immortality unravelling in a contemplative pace. Soon he has to return to the Charlie Company and face the rebuke by Sergeant Welsh (Sean Penn).

- On the deck of the ship which carries the soldiers to the Guadalcanal island, General Quintard (John Travolta) explains to Colonel Tall (Nick Nolte) the plan of the mission. The men of the Charlie Company are getting ready to disembark with mixed feelings of anxiety, fear and bewilderment.

- Once on the island, the soldiers explore the territory. As they progress towards a hill, they are attacked by the Japanese, who had fortified it, and suffer severe losses. Colonel Tall gives Captain Staros (Elias Koteas) a clear order to take over the hill at all cost. The green landscape is suddenly filled with smoke and fire, while the American soldiers advance against the 'invisible' enemies who are shooting and bombing relentlessly.

- Captain Staros disobeys Colonel Tall's orders for further attack. The plan is changed and a small group of volunteers with Captain Gaff (John Cusack) in charge outflank the enemy and destroy their machinegun post. The battalion takes one week's rest. Captain Staros is released of his duties.During their leave the soldiers try to forget but it is not possible. In voice-overs but also in private conversations we hear them confess their deepest thoughts and greatest fears about the war, about the loss of faith and their disillusionment.

- When this interlude is over, the C Company goes on with the next step of the operation but something goes wrong. Private Witt sacrifices his life and gets killed while trying to disorientate the enemy. The C Company finally leaves the island and is substituted by other soldiers. The film closes with another contemplative voice-over and the images of the wildlife and the sea.

Despite being a Hollywood production, the Thin Red Line seems to employ many aspects of the "art-cinema" narration. ${ }^{(14)}$ The film does not possess a clear beginning, middle or ending, while the narrative progression is fairly loose. The mission and the battle not only occupy a relatively limited portion of the film but also function as a pretext for an inquiry into the characters' mind. The emphasis lies on the character psychology and the subjective realism is enhanced by meditative voice-overs, daydreams and fantasies. Especially, in the last hour of the film after conquering the hill, there is hardly any progression of the story. We only see some soldiers engage in philosophical conversations about the brutality of war, another fantasizes about his wife or others wander around aimlessly trying to sort out their emotions. Moreover, the ending gives no sense of narrative closure because the military operation of taking over the island has not been accomplished nor has 
it been suppressed. The film seems to offer a few glimpses into the lives and deeds of some soldiers rather than a coherent account of the battle of the Guadalcanal.

As far as style is concerned, the battle scenes and the images of the dead and the wounded are very realistic. Contrary to most of the combat films of the WWII, ${ }^{(15)}$ the Thin Red Line does not hesitate to depict the human suffering and the heavy death toll of the war in their true colors. Close-ups of the soldiers' faces try to capture their fear and agony while the images of the dead bodies that fill the landscape unveil the hideousness of war. The use of close-ups in battle scenes was never common in the WWII films ${ }^{(16)}$ of the time and it can be regarded more as a legacy from the graphic realism of the Vietnam War films of the $1980 \mathrm{~s}^{(17)}$

At the same time, however, the scenes of the battles constitute a strange combination of realism and poetic symbolism. Against the backdrop of the bombs, the music is calm and, combined with the choreographical editing of the sequences, it creates a very poetic image of a brutal conflict. In addition, close-up shots of plants and animals appear frequently in the course of the film adding a very powerful symbolic dimension. What is clearly evident is that the images of the soldiers are seldom integrated into the same frame as wildlife, accentuating thus the sharp contrast between man and nature.

One of the most salient aspects of the film are the numerous voice-overs of different soldiers which come incessantly one after the other, revealing to us their thoughts and ruminations about the war, about the source of evil, about life and nature, about hope and death. We even have voice-overs by the characters that are not so appealing, like Colonel Tall, which makes them appear more human and vulnerable. The multiplicity of the speaking positions and the different perspectives of the narrative make it very difficult for the viewer to identify with any of the characters. Although Private Witt seems to gain some prominence, it would be inaccurate to consider him as the central hero.

The focus of the narration is constantly changing, shifting from character to character and preventing us from establishing a coherent identity for each one. According to Schatz, the combat film had always focused on the collective activities of a combat unit, ${ }^{(18)}$ but what is different in the Thin Red Line is the fact that we never see the main characters in action together. We don't know what kind of relations they have amongst themselves or even if they know each other. We glimpse into one character's life for a few moments only to move on to another in the next scene. We hear their parallel monologues or occasionally some conversations and only rarely do we see their paths meet, but even then we never have the sense of comradeship that was so explicit in the war films of the past. The film is like a landscape with people scattered all over and we "click" randomly on each character each time to see what he is doing or even more frequently to see what he is thinking.

What prevents identification even further is the choice of the actors and the unusual distribution of the roles in the film. All the main characters, like James Caviezel, Sean Penn, Ben Chaplin and John Cusack bear such a strong physical resemblance that it is difficult to distinguish them, especially in a combat situation. On the other hand, the famous stars of the film like John Travolta, Woody Harrelson and George Clooney only make cameo appearances that shatter the viewer's expectations. Travolta appears for a couple of minutes in the beginning of the film, Harrelson gets killed a few minutes after he has been introduced to the story and Clooney shows up for a few second in the closing moments of the film. This atypical use of the actors, combined with the multiple diegesis, breaks down the classical Hollywood tradition and creates a very strong estrangement effect, which is more common in art or counter-cinema. ${ }^{(19)}$

On the other hand, the Thin Red Line does not eschew completely some of the war film conventions that have been established throughout the Hollywood tradition of this genre. Like most World War II combat films, it comprises a historical background, a battle plan and moments of the daily life of the soldiers. ${ }^{(20)}$ Although the historical background is rather out of focus in this case, we still see the generals on the deck of the ship looking at maps and talking about the strategic significance of the target. The battle plan is to seize control over the Guadalcanal Island and a company of US soldiers takes over as a first mission to conquer a hill that has been fortified by the Japanese. The direct combat with the enemy combined with obstacles and moments of success have always been the indispensable elements of a combat film. Moreover, it is also very common to see American soldiers burning down villages, collecting 'war souvenirs', like the teeth of the Japanese soldiers, carrying photos of their wives ${ }^{(21)}$ and playing cards in their free time. 
Apart from the war film conventions, however, the film is also replete with melodramatic conventions, which are considered to be a characteristic not only of war films, but also of historical films in general. ${ }^{(22)}$ The use of flashbacks, daydreaming and sluggish meditative voice-overs is highly emotional and at the same time it creates a kind of aura around the events. Furthermore, the repetition of sentimental phrases and clichés like "I see another world", "Maybe all men got one big soul", "This great evil, where did it come from?" or "How did we lose the good that was given to us?" attach a very melodramatic tone to the film. Moreover, many scenes are emotionally loaded and could even be characterized as corny, like the moment when Captain Staros makes his farewells to his men saying: "You've been like my sons. You are my sons. My dear sons. You live inside me now. I'll carry you wherever I go." Finally, I should note the important role of the background music, which remains extremely poignant throughout the film and provides an emotional punctuation to the dramatic scenes of the battles.

\section{Representing War}

The Thin Red Line is about the Guadalcanal battle in the Pacific Ocean during the Second World War, but there is absolutely no attempt to create neither a historical account of this war nor a precise and accurate depiction of the past events. The film is concerned with War with a capital W, i.e. war as a universal phenomenon. As a result, there is no reference to the historical context or to the historical interests at stake and in this sense World War II merely stands for an archetype of War. The issues of race, nationality, ideology and strategy are purposefully de-emphasized, in order to explore the roots of such conflict in a more abstract level.

One of the main objectives of the film is to demonstrate that war is a great evil that mars the human soul and therefore there can be no justification for it. In the beginning, General Quintard explains to Colonel Tall that they should fight this war to protect their children but his words sound obsolete. At another point, Sergeant Welsh cries out loud: "Property! The whole fucking thing is about property!" Moreover, in a long introspective voice-over Private Witt utters: "This great Evil. Where does it come from? How is it still in the world? What sea, what route did it go from? Who is doing this? Who is killing us? Robbing us of life and laughter?"

What distinguishes the Thin Red Line from all its numerous 'cinematic predecessors' is exactly the lack of a just cause for this war. A lot of World War II combat films portrayed the hardships and the ugliness of warfare, but the war per se was never questioned. The soldiers had faith in the war and platitudes about protecting freedom or saving democracy were often used to explain the American involvement. ${ }^{(23)}$ The death toll of the war was heavy but justified. As the title at the end of Bataan says: "So fought the heroes of Bataan. Their sacrifice made possible our victories in the Coral Sea, at Midway, on New Guinea and Guadalcanal. Their spirit will lead us back to Bataan."(24)

On the other hand, the soldiers in the Thin Red Line are presented as pawns of the army that are easily consumable and replaceable. Colonel Tall is not interested in protecting his men and providing them with water because as he says, "If some of the men pass out, well hell, they'll have to pass out. They could also die from being fired. We have to move on!" At the end of the film, Sergeant Welsh observes in disgust: "All is a lie, everything you hear, everything you see. So much to spew out. They just keep coming one after the other [about the Colonels]. You are in a box, a moving box. They want you dead or in there lie." War is considered as a business run by a few people at the expense of the soldiers who sacrifice their lives for nothing.

As I have already noted, the main focus of the film is the individual experience of war from the soldiers' point of view. Their thoughts, feelings, sufferings and deepest fears are all conveyed to the viewer through their voice-overs, their expressive faces, the outbursts, the soliloquies and the fragmented conversations. Contrary to most World War II Combat films, there are no moments of glory and triumph nor there is any pride in the military service. ${ }^{(25)}$ In the Thin Red Line when an operation is successful the soldiers are unable to celebrate or relish the victory and remain frightened and speechless. Even during their holidays there is nothing to soothe their pain. As a Private confesses, "Nothing can make you forget it. Each time you start from scratch. War turns men into dogs. It poisons the soul". Little by little some men break down and lose control of the situation. In a state of shock a soldier shouts: "Who decides who is gonna live? Who decides who is gonna die? It is absurd!" Others become totally numb and admit to themselves: "You see dead people? They are 
meat, kid! They are no different that dead dogs, once you get used to the idea". Finally, some others, like Sergeant Welsh, are even more unfortunate; they cannot freeze their emotions and have to bear the burden of feeling the pain, of feeling the loss.

The portrayal of the Japanese is another interesting aspect of the film. Despite the superficial use of some clichés, such as calling them "the Japs", or showing the mutilated bodies of the American soldiers as sign of their violent nature, ${ }^{(26)}$ the film does not really distinguish the American soldiers from their opponents. They are all victims of the war and their sufferings are equally unjustified. When a group of Japanese is captured, the close-ups on their faces reveal the fear, the panic and the pain that any human being would experience. Some of them burst out in tears, others pray and others remain frozen, as if they are already dead. Private Witt looks at the face of a dead Japanese and wonders: "Are you righteous? Are you kind? Are you loved by all? Know that I was, too. Does your confidence lie in this? Do you imagine your sufferings would be less because you loved goodness? Truth?" Even those who were more aggressive towards the enemy in the beginning cannot keep all that hatred inside them for long. For instance, a soldier who collects the teeth of the Japanese and treats them like animals becomes in the end haunted by their cries and agonizing faces and is thus punished for his brutal behaviour. Therefore, the central argument of the film could be summarized again in another voice-over: "Maybe all men got one big soul where everybody is a part of. All faces of the same man. One big Self."

Finally, I would like to underline the strong binary oppositions that are quite prominent in the story and create a very powerful melodramatic atmosphere. The first opposition is between Colonel Tall and Captain Staros. The former is the ambitious, egocentric and cold-hearted military officer who sees this war as his great chance for distinction in the army. As he admits in an outburst of anger, "I've waited all my life for this. You don't know what it feels to be passed over. This is my first war!" At the same time, he remains focused on his goals and does not get carried away by his emotions. His decisions are very "realpolitik" and he has resigned to the fact that "war costs lives". On the other hand, Captain Staros is the benign lawyer who does not share the military mentality and consequently cannot fit into the reality of warfare and gets released of his duties. He is extremely sentimental and altruist and hence prefers to protect his men rather than sacrifice them in an ambivalent combat. When confronted with Tall's cynical views, he sincerely proclaims: "I don't like to see my men get killed."

The other important opposition is between the realist, down-to-earth Sergeant Welsh and the idealist, dreamy Private Witt. Although they are good friends and care about each other, they have completely opposite viewpoints in regard to the meaning of life. Sergeant Welsh is very pessimistic and sees only the madness of war whereas for Private Witt nothing can take away the beauty of the world. He suffers and cries for the pain that surrounds him but he also relishes the unspoiled nature and travels with his mind to places where happiness can be achieved. The opposition between these two characters is best illustrated in the following conversation:

S. Welsh: "In this world a man himself is nothing and there ain't no world but this one"

P. Witt: "You got that wrong. I've seen another world. Sometimes I think it was just my imagination."

S. Welsh: "Well, you've seen things I never will."

\section{Observations on the transformation of the war film genre}

As my analysis has tried to demonstrate, the Thin Red Line has very little in common with the long tradition of WWII combat films, as there are significant differences both at level of narrative style and the representations of the experience of war itself. These differences can be attributed to many diverse factors, but the most prominent one is the Vietnam War and its cinematic representations. As Doherty observes,

World War II films painted a portrait of victory and competence, of American true grit overpowering stormtrooper discipline and samurai fanaticism. Vietnam erased that image. The disrepute of the thousandday war transformed military action into a code phrase for legalized atrocities and made the soldier the butt of comedy, condescension and contempt. ${ }^{(27)}$

The films about Vietnam initiated a very critical stance towards the purpose of warfare and this is also the prevailing concept in the Thin Red Line. Moreover, the brutal realism combined with strong elements 
of melodrama are the familiar aspects of films like Platoon, the Deer Hunter and Apocalypse Now, whose influence is quite evident in the film. ${ }^{(28)}$ In addition, the depiction of unholy warriors, the conflicts within the military ranks and, above all, the focus on the subjective experience of war are all elements that the Thin Red Line apparently inherited from the Vietnam War film tradition.

However, the representation of World War II seen through the experience of Vietnam inevitably requires a significant detachment from the historical context. Two totally different historic events with different political and social backgrounds, goals and implications cannot be approached in the same manner without some historical or ideological compromises. This is exactly the reason why the Thin Red Line does not really represent the Second World War, but a sort of archetypical war with no historic reference. In this sense, it could be regarded as a nostalgia film which wants to give us images of a past event while disconnecting it from its place in history and emptying it from its historical meaning. As Jameson observes about nostalgia films,

The increasing number of films about the past are no longer historical; they are images, simulacra, and pastiches of the past. They are effectively a way of satisfying a craving for historicity, using a product that substitutes for and blocks it. ${ }^{(29)}$

The Thin Red Line touches upon a historical conflict without any concern for investigating history or evaluating the wider parameters that define an event like war. It seems as if Malick attempts to "absorb the wide-shot complications of political and social history by filling the frame with over-determined moral and humanistic dilemmas, personal emotions and fears that transcend any historical instance."(30)

By constantly repeating that War is an evil with no justification and by accentuating the randomness of death and the inability of a single man to make a difference to this world, it blocks any understanding of the historical and social implications of the past event. Additionally, the death of Private Witt and the defilement of his hopes and dreams for another world symbolize the end of a utopian vision and the acceptance of the harsh reality.

On the whole, it looks as if the heavily loaded ideological role of the World War II combat films and the triumphal depictions of the Hollywood war tradition have been superseded by a poetic and transcendental investigation into the metaphysics of War. We know that the approach endorsed by The Thin Red Line is always open to criticism, as it tends to replace the myth of patriotism that prevailed in its predecessors with the myth of war as the great Evil that we don't know where it comes from and all we have to do is endure it. With this almost inherent shortcoming in mind, I believe that Malick's depiction of war should, nevertheless, be highlighted in the cinematic history as a kind of critical amalgam or meta-war commentary that encompasses many of the 'continuities and ruptures' linking one American conflict to another throughout history. ${ }^{(31)}$

[A shorter version of this article was presented at the conference The Stories of World War II, Netherlands American Studies Conference 2004, Vrije Universiteit, Amsterdam (21-23 June, 2004)]

\section{Notes}

1. Coincidentally, Steven Spielberg's Saving Private Ryan was released in the same year. 2. For this observation, see Macnab, J., "Soldier stories", Sight \& Sound, vol. 9, nr. 2, pp 14. 3. MacCabe, C., "Bayonets in paradise", Sight \& Sound, vol. 9, nr. 2, pp. 10. 4. See Schatz, T. "World War II and the Hollywood 'war film"', in Browne, N.(ed.), Refiguring American film genres: history and films, Berkeley: University of California Press, 1998, pp. 89. 5. See Doherty, T., Projections of war: Hollywood, American culture and World War II, New York: Columbia University Press, 1993, pp. 6. 6. See Shull, M.S. and Wilt, E. D., Hollywood war films 1937-1945, North Carolina and London: McFarland and Co., 1996, pp. 162. 7. See Schatz, T., ibid., pp. 103. 8. See Shull, M.S. and Wilt, E.D., ibid, pp. 177. 9. See Dick, B., The Star-spangled screen: The American world war II film, Kentucky: University Press of Kentucky, 1985, pp. 231. 10. See Manvell, R., Films and the Second World War, New York: Delta, 1974, pp. 321. 11. See Solomon's analysis of Patton in Solomon, S.J., Beyond Formula: American film genres, Harcourt Brace, Jovanovich, 1976, pp. 292-5. 12. See Doherty, T., Projections of war: Hollywood, American culture 
and World War II, New York: Columbia University Press, 1993, pp. 285. 13. Ibid. pp. 297. 14. For a detailed description of the art-cinema narration, see Bordwell, D., Narration in the Fiction Film, London: Routledge, 1986, pp. 205-33. 15. According to Shull, M.S. and Wilt, E. D., "even the most realistic Combat films like Guadalcanal Diary and Battaan are extremely restrained in the actual depiction of death and injury in the battlefield". See Shull, M.S. and Wilt, E. D., Hollywood war films 1937-1945, North Carolina and London: McFarland and Co., 1996, pp. 179. 16. As Dick observes, it was only in the 50s that the long shot contracted to medium shot. See Dick, B., The Star-spangled screen: The American world war II film, Kentucky: University Press of Kentucky, 1985, pp. 131. 17. For the extended use of close-ups in the Vietnam War films, see Corrigan, T., A cinema without walls: movies and culture after Vietnam, New Jersey: Rutgers University Press, 1991, pp. 42 and Bates, M.J., The Wars we took to Vietnam: Cultural conflict and storytelling, Berkeley and Los Angeles: University of California Press, 1996, pp. 106. 18. See Schatz, T. "World War II and the Hollywood 'war film"", in Browne, N.(ed.), Refiguring American film genres: history and films, Berkeley: University of California Press, 1998, pp. 108-9. 19. For the features of counter-cinema see Stam, R., Burgoyne, R. and Flitterman-Lewis, S., New Vocabularies in Film Semiotics: Structuralism, Post-structuralism and Beyond, London: Routledge, 1992, pp. 198. 20. For the conventions of world war II combat films, see Kane. K., R., Critical Analysis of World War II Combat Films 1942-45, Ann Arbor, Michigan: University Microfilms International, 1981. 21.Shull, M.S. and Wilt, E. D., Hollywood war films 1937-1945, North Carolina and London: McFarland and Co., 1996, pp. 177 and 181. 22. Landy, M., Cinematic uses of the past, Minnesota, London: University of Minnesota Press, 1997, pp. 17. 23. See Kane, K., R., Critical Analysis of World War II Combat Films 1942-45, Ann Arbor, Michigan: University Microfilms International, 1981. 24. Quoted in Dick, B., The Star-spangled screen: The American world war II film, Kentucky: University Press of Kentucky, 1985, pp. 133-4. 25. See Kane, K., R., Critical Analysis of World War II Combat Films 1942-45, Ann Arbor, Michigan: University Microfilms International, 1981, pp. 181. 26. As I briefly mentioned in my introduction the portrayal of the Japanese in WWII combat films, especially during the war, had been more than denigrating. The Japanese were barbaric, bestial and they belonged to the jungle. See Kane, K., R., Critical Analysis of World War II Combat Films 1942-45, Ann Arbor, Michigan: University Microfilms International, 1981, 21-3. 27. See Doherty, T., Projections of war: Hollywood, American culture and World War II, New York: Columbia University Press, 1993, pp. 282. 28. As Bates remarks about Platoon, "its realism is more rhetorical than structural, a thin veneer over a substrate of melodrama", which in many respects applies to the Thin Red Line. See Bates, M. J., The Wars we took to Vietnam: Cultural conflict and storytelling, Berkeley and Los Angeles: University of California Press, 1996, pp. 110. 29. Fredric Jameson quoted in Corrigan, T., A cinema without walls: movies and culture after Vietnam, New Jersey: Rutgers University Press, 1991 pp. 35. 30. This is another remark about Platoon, which describes quite accurately the purpose of Thin Red Line. See Corrigan. T., ibid. pp. 42.

31. I am paraphrasing one of John Hodgkins observations about the film. See Hodgkins, J., "In the Wake of Desert Storm: A consideration of Modern World War II Films," Journal of Popular Film and Television, vol. 30, nr. 2 (Summer 2002), p. 74-84.

\section{References}

Basinger, J., "Living-room war", American Film, vol. 10, nr. 10, September 1985, pp. 62-6. Bates, M. J., The Wars we took to Vietnam: Cultural conflict and storytelling, Berkeley and Los Angeles: University of California Press, 1996. Bordwell, D., Narration in the Fiction Film, London: Routledge, 1986. Ciment, M., "Terrence Malick", Positif, nr. 446, April 1998, pp. 52-8. Corrigan, T., A cinema without walls: movies and culture after Vietnam, New Jersey: Rutgers University Press, 1991. Coursodon, J-P. and Garsault, A., "Le film du guerre", Positif, nr. 452, October 1998, pp. 39-46. Dick, B., The Star-spangled screen: The American world war II film, Kentucky: University Press of Kentucky, 1985. Doherty, T., Projections of war: Hollywood, American culture and World War II, New York: Columbia University Press, 1993. Henry, M., Viviani, C., Ciment, M. and Niogret, H., "Terrence Malick", Positif, nr. 457, March 1999, pp. 4-16. Higuinen, E., "Les racines du mal," Cahiers du cinéma, nr. 533, March 1999, 64-5. Hodgkins, J., "In the Wake of Desert Storm: A consideration of Modern World War II Films," Journal of Popular Film and Television, vol. 30, nr. 2 (Summer 2002), p. 74-84. Kane, K., R., Critical Analysis of World War II Combat Films 1942-45, Ann Arbor, Michigan: University Microfilms International, 1981. Landy, M., Cinematic uses of the 
past, Minnesota, London: University of Minnesota Press, 1997. Lichty, L.W. and Carroll, R. L, "Fragments of fear: Platoon(1986)", in O'Connor, J. and Jackson, M., American History, American film: interpreting the Hollywood Image, 1998. MacCabe, C., "Bayonets in paradise", Sight \& Sound, vol. 9, nr. 2, pp. 10-3. Macnab, J., "Soldier stories", Sight \& Sound, vol. 9, nr. 2, pp 14 __, "The thin red line", Sight \& Sound, vol 9, nr. 3, March 1999, pp. 53-4. Manvell, R., Films and the second world war, New York: Delta, 1974 McCarthy, T., "Malick draws a ravishing "line," Variety, No. 6, December 21, 1998, pp. 73, 80. Rosenstone, R., "The future of the past", in Sobchack, V., The persistence of history: cinema, television and the modern event, New York and London: Routledge, 1996. Schatz, T. "World War II and the Hollywood "war film", in Browne, N. (ed.), Refiguring American film genres: history and films, Berkeley: University of California Press, 1998, pp. 89-128. Shull, M.S. and Wilt, E. D., Hollywood war films 1937-1945, North Carolina and London: McFarland and Co., 1996. Smith, G., "Let there be light", Film Comment, vol. 35, nr. 1, Jan-Feb 1999, pp. 8-11. Solomon, S.J., Beyond Formula: American film genres, Harcourt Brace, Jovanovich, 1976. Stam, R., Burgoyne, R. and Flitterman-Lewis, S., New Vocabularies in Film Semiotics: Structuralism, Post-structuralism and Beyond, London: Routledge, 1992. Whalen, T., "Maybe all men got one big soul: the hoax within the metaphysics of Terrence Malick's The thin red line", Literature/Film Quarterly, vol. 27, nr. 3, 1999, pp. 162-6.

\section{Author Information}

Eleftheria THANOULI is an Assistant Professor in Film Theory at the Film Department at Aristotle University of Thessaloniki. Her book Post-classical Cinema: An International Ioetics of Film Narration is forthcoming from Wallflower Press in March 2009. 